\title{
Effect of Gamma Radiations on Colocasia Leaves in Enhancing Shelf Life
}

\author{
Lilesh H. Pustode* and D.T. Bornare \\ Department of Agricultural Engineering, Maharashtra Institute of Technology, \\ Aurangabad, Maharashtra, India \\ *Corresponding author
}

\section{Keywords}

Cobalt-60,

Colocasia leaves,

Gamma Radiations,

Irradiation, Post

harvest losses, Shelf life

Article Info

Accepted:

20 May 2018

Available Online:

10 June 2018

\section{A B S T R A C T}

Fresh produce has enormous potential to contribute in food and nutritional security. It also contributes with essential micronutrients in the daily diet. The indigenous fresh produce has a short shelf life and they get affected during storage and transportation due to microbial spoilage. Irradiation treatment could also be applied to mitigate this problem. Irradiation helps to eliminate various microorganisms, delay ripening, sprout inhibition and extension of shelf life of fresh produce. Cobalt-60 is the radioisotope used as a source of gamma radiations. Treatment of gamma radiation was carried out with doses of 1.5, 2.0, $2.5 \mathrm{kGy}$. Gamma radiation in a controlled amount between the range of 1.5-2.5 kGy penetrates the pre-packed Colocasia esculenta leaves to extend the shelf life. Gamma radiations at 1.5 and $2.5 \mathrm{kGy}$ was effective in reducing microbial content, enhancing shelf. Storage studies show that Colocasia leaves treated with $1.5 \mathrm{kGy}$ enhance the shelf life for 18-21 days without affecting nutritional quality and safety of food. This process is effective in reducing bacterial as well as fungal growth. Gamma radiations did not affect nutritional quality of Colocasia leaves by application of 1.5-2.5 kGy as major nutrients such as proteins, fats are not affected significantly. Minor nutrient such as vitamin $\mathrm{C}$ was affected by high dose. Also application of spent nuclear fuel in such processing unriddles the problems of nuclear waste disposal and management in some extent. Thus, such technology can augment processing of fresh produce and control post-harvest losses in developing countries like India.

\section{Introduction}

Leafy vegetables have enormous potential to provide food and nutritional security and important constituents of the diet including minor nutrients such as minerals and vitamins to the people. With increasing public awareness and heath consciousness the rate consumption of leafy vegetables tremendously increased day by day in recent years. (Kamat et al., 2005). Colocasia leaves (Colocasia esculenta leaves) also called as eddoe, alu or arvi, is a tropical tuber crop belongs to an Aroid family (Aracaceae) and it is in the genus Colocasia. It is indigenous crop, very popular for its underground stem, and it is widely produced throughout the world for its leaves and corns. Colocasia leaves contain protein, carotenoids and certain minerals which are needed for vision, immunity, bone health and 
other metabolic activities. (Temesgen 2015; Henry, 2001 and Krishnapriya 2017). Colocasia leaves grown throughout the tropic and subtropic originated from the tropical region of Asian countries between India and Indonesia (Matthews 2004).

Since antiquity, preservation of food is a major concern as the increasing demand of food for drastic growth of population. Post harvest losses of fresh agricultural produce are major global problems (Abdullah et al., 2016) which are unriddle by the application of food irradiation processing to augment transportation of vegetables and consumptions for longer periods of time after harvesting. As compared to the general preservation techniques and traditional techniques, the effect of gamma radiations is more effective to eliminating microbial growth (Golan et al., 2017 and Kortei et al., 2015). Many studies (Gunes et al., 2000, Golan et al., 2017, Majeed et al., 2014) showed that, the application of gamma irradiation is one of the most effective technology in extension of shelf life and delay ripening, microbial elimination. Ehlermann, (2016) concluded that, with increasingly restrictive regulations or prohibition on the use of chemical fumigants for insect and microbial control in the food industry, irradiation is a best alternative to protect food against insect, pest damage and as a quarantine treatment for fresh produce.

\section{Materials and Methods}

The present study is an attempt made to enhance the shelf life of Colocasia leaves by using gamma irradiation. Treatment of gamma radiations on Colocasia leaves was done in Agrosurge Irradiators India Pvt. Ltd, Facility Krushak, Lasalgaon (M.S.) India and other analytical work was carried out at the Department of Agricultural Engineering, Maharashtra Institute of Technology, Aurangabad, (M.S) India.

\section{Procurement of raw materials}

Colocasia leaves were obtained from the local vegetable market of Lasalgaon, Krushi Utpadan Samiti Market, Lasalgaon, Nashik, Maharashtra, India. Raw material was collected from the nearest market from irradiation facility.

\section{Treatment with various doses of gamma radiations}

Cleaning of Colocasia leaves

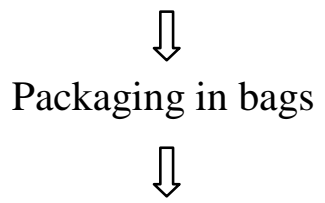

Placed on conveyor system<smiles>[CH]</smiles>

Irradiation of leaves by gamma radiations (Cobalt 60 source)<smiles>[CH]</smiles>

Unloading from irradiation chamber<smiles>C=C[SiH3]</smiles>

Colocasia leaves were irradiated using Agrosurg Irradiators India Pvt. Ltd, FacilityKrushak located at Lasalgaon, and this facility mostly used for treatment of onions, mango, pomegranate, onion powder, other fruits and vegetables etc. Cobalt-60 irradiator emits gamma radiations at a controlled amount. The leaves were exposed to various radiation doses range between 1.5- $2.5 \mathrm{kGy}$. The chemical dosimeters ceric cerous was used for dose measurement.

\section{Microbial analysis}

Irradiated and unirradiated samples of Colocasia leaves were analysed for the 
bacterial, fungal and coliform colony forming units (CFU) by the standard plate count methodology. Analysis was also carried out in $0,6,12,18$ days of storage at room temperature $\left(25^{\circ} \mathrm{C}\right)$ and under refrigerated conditions $\left(4^{\circ} \mathrm{C}\right)$. Serial dilutions were prepared using sterile phosphate buffer. Plate count agar (Nutrient agar) for bacterial plate count, potato dextrose agar (PDA) for fungal. Serial dilution method was used to dilute the concentration of cells and then by using spread plate techniques, plates were prepared. PCA and PDA plates were incubated at $32^{\circ} \mathrm{C}$ for $48 \mathrm{~h}$, and PDA plates were incubated at $22^{\circ} \mathrm{C}$ for $72 \mathrm{~h}$. Plates with CFUs between 25 and 300 were utilized to calculate the CFU/100g. The CFUs reported reflect the average of 4 plates.

\section{Moisture content}

Determination of moisture content by using hot air oven drying method. $10 \mathrm{~g}$ of samples of each material will take in pre-weighed empty Petri plate and dried in hot air oven at $105^{\circ} \mathrm{C}$ till constant weight obtain. Plates were placed in desiccators. The moisture content will calculate by using formula. (Ranganna, 1986).

$\%$ moisture of sample $=$

Initial weight - Final weight

$$
\text { Sample weight }
$$

\section{Protein}

Total protein was estimated by Lowry's method in which reagents required are (a) 50 $\mathrm{ml}$ of $2 \%$ sodium carbonate mixed with $50 \mathrm{ml}$ of $0.1 \mathrm{~N} \mathrm{NaOH}$ (b) $10 \mathrm{ml}$ of $1.56 \%$ copper sulphate solution mixed with $10 \mathrm{ml}$ of $2.37 \%$ sodium potassium tartarate solution. Analytical reagents were prepared by mixing 2 $\mathrm{ml}$ of (b) with $100 \mathrm{ml}$ of (a) Folin - Ciocalteau reagent solution $(1 \mathrm{~N})$ Dilute commercial reagent $(2 \mathrm{~N})$ with an equal volume of water on the day of use. BSA solution was prepared by mixing a stock BSA solution $(1 \mathrm{mg} / \mathrm{ml})$ and water in the test tube. The BSA range was 0.05 to $1 \mathrm{mg} / \mathrm{ml}$. From these dilutions, pipette out $0.2 \mathrm{ml}$ protein solution to test tubes and add $2 \mathrm{ml}$ of alkaline copper sulphate reagent. Well mixed solutions incubated at room temperature for $10 \mathrm{~min}$. Then add $0.2 \mathrm{ml}$ of reagent Folin Ciocalteau solution to each tube and incubate for $30 \mathrm{~min}$. Zero the colorimeter with blank and measure the absorbance at 660 $\mathrm{nm}$. Plot the absorbance against protein concentration to get a standard calibration curve. Check the absorbance of unknown sample and determine the concentration of the unknown sample using standard graph (Lowry 1951, Wilson 2000).

\section{Fat}

Fat content was determined by using the Soxhlet apparatus method. 2gm of powder sample weight accurately into a dry thimble \& extracted using petroleum ether $\left(60-80^{\circ} \mathrm{C}\right.$ boiling range) as solvent for 3 hours. The fat extract collects in a previously weighed dry flat bottom flask and separate from the solvent by evaporating over a hot water bath. The flask dry in an oven at 80-100c and cooled till constant weight was obtained. (Ranganna, 1986)

$\%$ Fat $=$

Final weight of beaker - Empty weight of beaker

Sample weight

\section{Ash}

Ash content was determined by the use of muffle furnace. In this $1 \mathrm{~g}$ of the sample was ignited in a muffle furnace for $4-6 \mathrm{hrs}$. At $550^{\circ} \mathrm{C}$. Total ash will expressed as a 
percentage. The ash will calculate using following formula. (Ranganna, 1986)

$$
\% \text { of Ash }=\frac{\text { Weight of ash }}{\text { Sample weight }} \times 100
$$

\section{Fiber estimation}

Moisture and fat free sample weight $2 \mathrm{~g}$ were digested with $200 \mathrm{ml}$ of 1.25 percent $\mathrm{H} 2 \mathrm{SO} 4$ by gently boiling for half an hour. The content filter and the residues were washed several times with hot distilled water till it became free from acid. Acid free residue was transferred to the same flask to which $200 \mathrm{ml}$ of 1.25 per cent $\mathrm{NaOH}$ will add. Digest the sample again for half an hour, filter it and residue was again washed with hot distilled till it became alkali free. The residue was dried in an oven overnight at $100^{\circ} \mathrm{C}$ and weigh and then placed in a muffle furnace at $600^{\circ} \mathrm{C}$ $\left( \pm 50^{\circ} \mathrm{C}\right)$ for 4 hours. The loss in weight after ignition the sample represents the fiber in the sample (Ranganna, 1986).

$\%$ Crude Fiber $=\frac{\mathrm{W} 1}{\mathrm{~W}} \times 100$

\section{Vitamin C}

Ascorbic acid content was determined by titrating a known weight of sample with 2, 6dichlorophenol indophenol dye using oxalic acid. The 2, 6-dichlorophenol dye which is blue in alkaline solution and red in acid solution reduces ascorbic acid to a colorless form. Ascorbic acid is expressed as mg/100g by using given formula (Ranganna, 1986).

Ascorbic acid (mg/100gm) $=$ (Titrate $\times$ Dye Factor $\times$ Volume made up $\times 100) /($ Aliquot of extract taken for estimation $\times \mathrm{Wt}$. Or Vol.of sample taken for estimation).

\section{Results and Discussion}

The present study was carried for one year in Maharashtra Institute of Technology, Aurangabad during the year 2017-18 Vegetables were procured from the local market during the study. The applied dose range of 1.5- $2.5 \mathrm{kGy}$ was selected for evaluating the effect of gamma irradiation on minimally processed Colocasia leaves. Before irradiation leaves were packaged in perforated polythene bags. After irradiation samples were stored for evaluation at ambient temperature and refrigerated temperature.

This study shows that by eliminating the microbial load on Colocasia leaves, the shelf life of leaves were founded in the having freshness and acceptance upto 18- 21 days at $4^{\circ} \mathrm{c}$. Comparing the samples at room temperature and refrigerated conditions, I conclude that irradiation processing is effective for leafy vegetables if stored in cold storage $\left(4^{\circ} \mathrm{c}\right)$, also mentioned on the application of high dose than critical limits may be resulted in the depletion of shelf life.

Optimum dose such as $1.5 \mathrm{kGy}$ was sufficient in enhancing the shelf life of Colocasia leaves.

Microbial analysis of sample was done at CARS Lab, Maharashtra Institute of Technology, Aurangabad, (M.S.). PCA and PDA were used as media for bacterial and fungal growth respectively. Effect of gamma radiations was stronger on Colocasia leaves which inhibit the growth of microorganisms after treatment. Elimination of microbial growth was carried out at 1.5, 2.0, and 2.5 kGy, showed no colony count on plates which contain irradiated sample during storage at refrigerated temperature for $0,6,12,18$ days.

Where, C- $0 \mathrm{kGy}, \mathrm{T}_{1}-1.5 \mathrm{kGy}, \mathrm{T}_{2}-2.0 \mathrm{kGy}$ and $\mathrm{T}_{3}-2.5 \mathrm{kGy}$. 
Table.1 Microbial analysis of irradiated and unirradiated Colocasia leaves

\begin{tabular}{|c|c|c|c|c|c|}
\hline \multirow{3}{*}{$\begin{array}{l}\text { Media } \\
\text { PDA }\end{array}$} & & \multicolumn{4}{|c|}{ Duration } \\
\hline & & \multirow{2}{*}{$\begin{array}{l}0 \text { days } \\
41 \times 10^{4}\end{array}$} & \multirow{2}{*}{$\begin{array}{l}6 \text { days } \\
44 \times 10^{4}\end{array}$} & \multirow{2}{*}{$\begin{array}{l}12 \text { days } \\
48 \times 10^{4}\end{array}$} & \multirow{2}{*}{$\begin{array}{l}18 \text { days } \\
49 \times 10^{4}\end{array}$} \\
\hline & $\mathrm{C}$ & & & & \\
\hline & $\mathrm{T}_{1}$ & 0 & 0 & 0 & 0 \\
\hline & $\mathrm{T}_{2}$ & 0 & 0 & 0 & 0 \\
\hline & $\mathrm{T}_{3}$ & 0 & 0 & 0 & 0 \\
\hline \multirow[t]{4}{*}{ PCA } & $\mathrm{C}$ & $109 \times 10^{4}$ & $112 \times 10^{4}$ & $120 \times 10^{4}$ & $172 \times 10^{4}$ \\
\hline & $\mathrm{T}_{1}$ & 0 & 0 & 0 & 0 \\
\hline & $\mathrm{T}_{2}$ & 0 & 0 & 0 & 0 \\
\hline & $\mathrm{T}_{3}$ & 0 & 0 & 0 & 0 \\
\hline
\end{tabular}

The values expressed in CFU/gm. Values are average of three determinations.

Table.2 Proximate analysis of irradiated and unirradiated Colocasia leaves per $100 \mathrm{~g}$

\begin{tabular}{|l|l|l|l|l|l|l|}
$\begin{array}{l}\text { Dose } \\
\text { (kGy) }\end{array}$ & Moisture & Fat & Proteins & Ash & $\begin{array}{l}\text { Crude } \\
\text { fiber }\end{array}$ & $\begin{array}{l}\text { Vitamic } \\
\text { C }(\mathbf{m g} / \mathbf{g})\end{array}$ \\
\hline $\mathbf{0}$ & $85.27 \pm 0.1$ & $0.68 \pm 0.01$ & $3.42 \pm 0.01$ & $2.27 \pm 0.01$ & $5.35 \pm 0.2$ & $5.23 \pm 0.2$ \\
\hline $\mathbf{1 . 5}$ & $84.27 \pm 0.2$ & $0.67 \pm 0.02$ & $3.41 \pm 0.01$ & $2.2 \pm 0.1$ & $5.34 \pm 0.28$ & $3.97 \pm 0.1$ \\
\hline $\mathbf{2 . 0}$ & $83.02 \pm 0.9$ & $0.68 \pm 0.01$ & $3.40 \pm 0.02$ & $2.2 \pm 0.1$ & $5.21 \pm 0.3$ & $3.89 \pm 0.2$ \\
\hline $\mathbf{2 . 5}$ & $83.19 \pm 0.7$ & $0.68 \pm 0.01$ & $3.41 \pm 0.01$ & $2.26 \pm 0.01$ & $5.08 \pm 0.07$ & $2.54 \pm 0.02$ \\
\hline
\end{tabular}

Values represent the mean $\pm \mathrm{SD}$

Figure.1 Effect on shelf life at room temperature and refrigerated condition

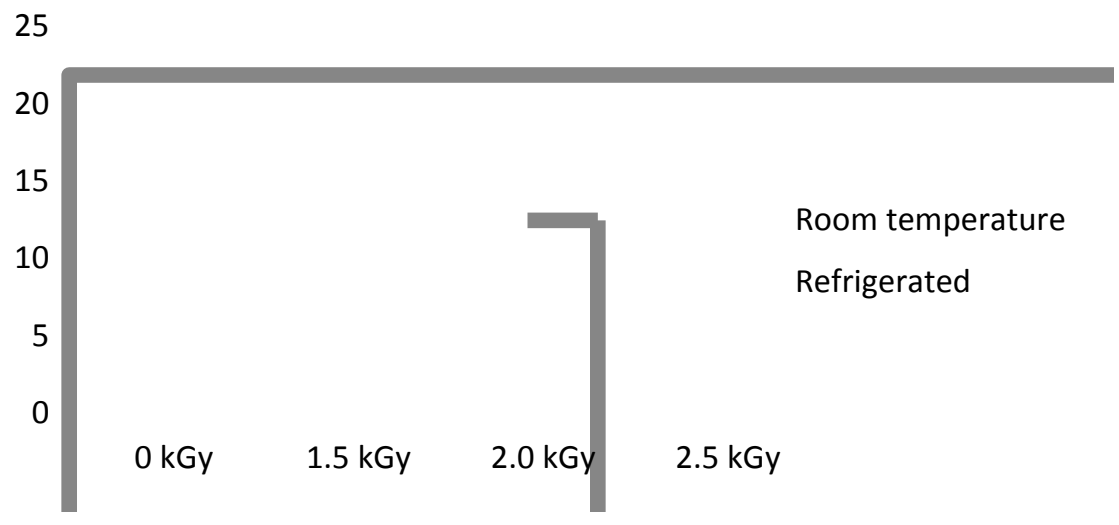

The effect of gamma radiation processing of irradiated and unirradiated Colocasia leaves is presented in table 1 . The data obtained from the analysis indicated that gamma radiations did not made depletion of nutrients such as fat, proteins. The data obtained during analysis of protein content by Lowry method was significant. About
$3.41 \%$ protein was found in the leaves which not alter by various doses of 1.5, 2.0, $2.5 \mathrm{kGy}$. There was no loss of significant amounts of protein due to irradiation processing.

In conclusion, fresh local variety of Colocasia leaves were irradiated between 
$1.5-2.5 \mathrm{kGy}$. After irradiation the Colocasia leaves were kept at room temperature and refrigerated temperature. It was observed that irradiated at $1.5 \mathrm{kGy}$ and kept at $4^{\circ} \mathrm{C}$ having freshness and accetance up to 18-21 days. This dose eliminating microbial load that could damage Colocasia leaves. Nutritional quality of Colocasia leaves was not affected by $1.5 \mathrm{kGy}$, did not cause any deleterious effect on leaves and it was found that nutrients are adequate after irradiation processing. Therefore, leafy vegetables can be transported and consumed for a long period of time after harvesting.

\section{References}

Abdullah R., Iftikhar S., Iqtedar M., Kaleem A., Iqbal I., Naz S. 2016 Gamma irradiation as a quarantine treatment to prevent post harvest spoilage ofDaucusCarrota L.J. BIOL, 6,109115.

Ehlermann, D.A.E. 2016 Wholesomeness of Irradiated Food. Radiat. Phys. Chem., 125, 24-29.

Golan B., Follett R. 2017. Irradiation for quality improvement, microbial safety and phytsosanitation of fresh produce, Academic Press.

Gunes G., Watkins and J. Hotchkiss 2000. Effect of irradiation on respiration and ethylene production of apple slices J.Sci. of Food and Agri 1169-1175. Int. J. Curr. Microbiol. App. Sci 3 (4): 549-555.

Henry, R.J. 2001. Plant genotyping: The DNA fingerprinting of plants.

Kamat AS, Ghadge N, Ramamurthy MS and Alur MD, 2005. Effect of low- dose irradiation on shelf life and microbiological safety of sliced carrot J.Sci Food Agric85: 2213-2219

Kortei N, Odamtten G., Obodai M., Appiah V., Akonor P., 2015. Determination of color parameters of gamma irradiated fresh and dried mushrooms during storage. Croation J. Food Tech., Biotech., Nutri. 10(1-2), 66-71.

Krishnapriya T. V., Suganthi A. Biochemical and phytochemical analysis of Colocasia esculenta (L.) Schott tubers. Int. J. Res. In Pharm. And Pharm Sci. 21-25.

Lowry, O.H., Rosebrough, N.J., Farr, A.L., and Randall, R.J. (1951) J.Biol.Chem 193: 265.

Majeed A., Muhammad z.,Majid A, A.H. Shah and Hussain M. Impact of low doses of gamma irradiation on shelf life and chemical quality of strawberry (fragariaxananassa) cv. 'corona' The Journal of Animal \& Plant Sciences, 24(5): 2014, 1531-1536.

Matthews, P. 2004. Genetic diversity in taro, and the preservation of culinary.

Melese Temesgen and Negussie Retta Nutritional Potential, Health and Food Security Benefits of Taro Colocasia Esculenta (L.): A Review, Food Sci. Qua. Management 23-30.

Ranganna, S., 1986. Handbook of Analysis and Quality Control for Fruit and Vegetable Products Tata McGraw-Hill Education, 1986 - Food.

Wilson, K. and Walker, J. (2000) 'Practical Biochemistry: Principles and Techniques", Cambridge University Press.

\section{How to cite this article:}

Lilesh H. Pustode and Bornare, D.T. 2018. Effect of Gamma Radiations on Colocasia Leaves in Enhancing Shelf Life. Int.J.Curr.Microbiol.App.Sci. 7(06): 2812-2817.

doi: https://doi.org/10.20546/ijcmas.2018.706.329 